\title{
Sciendo
}

Administration, vol. 69, no. 1 (2021), pp. 35-48

doi: 10.2478/admin-2021-0003

\section{Local government, 2020}

\author{
Fergal O'Leary \\ Institute of Public Administration, Ireland
}

In a year that many people will be happy to forget, the Covid-19 pandemic wrought untold disruption and distress across society. From March the annual work programmes of councils largely gave way to emergency management. New priorities and challenges emerged as the pandemic's broad impact meant that local authorities played different support roles, and they continue to do so - not only in working closely with the other principal response agencies (the Health Service Executive and An Garda Síochána), but also in terms of supporting local businesses and communities through a torrid period. From the local enterprise offices (LEOs) to the local community development committees (LCDCs) and library services, a coordinated and determined response saw all local authorities help mitigate Covid's impact on the ground.

February's general election eventually led to the formation in June of a new coalition government with a lengthy programme of policy commitments for the next five years. Under a reorganised department, Darragh O'Brien, TD, was appointed the Minister for Housing, Local Government and Heritage.

\section{Community development}

Community development was a crucial area of work for councils during the pandemic as their local leadership role came to the fore. They were central to the government's 'In This Together' and 'Keep Well' community support campaigns. 
Under the Framework for Local Authority Community Support Response, in early April each local authority established a Community Call forum and dedicated helpline (Department of Housing, Local Government and Heritage, 2020a). Working with state agencies, and community and voluntary groups, this support structure enabled councils to effectively coordinate a local response to meet the needs of vulnerable people. The innovative efforts undertaken by the councils - in partnership with local stakeholders - gained much media attention and highlighted the coordination role they play in community development. Around 59,000 calls had been received through the Community Call helplines by the end of 2020 (Department of Housing, Local Government and Heritage, 2020d).

Financial support was provided to the community and voluntary sector by a stability fund, the July Stimulus Plan and Budget 2021, with the local authorities administering this extra funding.

In December a National Volunteering Strategy 2021-2025 was published by the Department of Rural and Community Development. The Covid-19 crisis has underscored the invaluable work of volunteers across the country. Through the LCDCs, the public participation networks (PPNs) and local development companies, the local authorities help coordinate and support volunteering efforts locally. Therefore, in this strategy, they are recognised as important stakeholders and will be heavily involved in helping realise its vision (Department of Rural and Community Development, 2020).

\section{Enterprise support}

Similarly, big efforts were made by the local councils to support entrepreneurs and small businesses struggling to keep financially afloat during 2020. The imposition and lifting of public health restrictions severely disrupted normal trading from March onwards. The LEOs were at the heart of the government's response to support local businesses. As well as providing their usual services, the LEOs administered the Business Restart Grant. As part of the government's Roadmap for Reopening Society \& Business, introduced in May, this $€ 250$ million business support fund was subsequently increased by the July Stimulus Plan (Department of Enterprise, Trade and Employment, 2020). The grant scheme was intended to assist micro and small businesses reopen and reemploy staff. By the end of 2020, the thirty-one LEOs had administered $€ 609$ million in grant funding (Department of Housing, Local Government and Heritage, 2020d). 
The LEOs got behind a 'Look for Local' campaign to encourage Irish consumers to buy locally. As part of the campaign, a public survey carried out on behalf of the LEOs showed that 85 per cent of respondents thought that more businesses were trading online in 2020 than in 2019, and that 83 per cent planned to support more local businesses in 2021. More and more Irish businesses are now trading online thanks in no small part to the work of the enterprise offices. In 2020 they approved over 11,000 trading online vouchers, an increase of 800 per cent on the figure for 2019 (Local Enterprise Offices, 2020). Such support is particularly important for non-essential retailers unable to open their doors to customers because of the government's restrictions.

The work of the LEOs will continue apace as jobs creation and economic recovery become a priority in post-Covid Ireland. The Programme for Government (PfG) mentions strengthening Ireland's approach to enterprise. This will see an expanded role for the LEOs, who will provide grant support directly to businesses with over ten employees (Department of the Taoiseach, 2020).

There was also the matter of Brexit to contend with, and in 2020 the LEOs continued their work of getting Irish businesses ready for trading with Britain after the transition period. Despite the trade deal between the EU and the UK, the LEOs will still be busy in 2021 owing to Brexit. Support will need to be given to affected small businesses struggling to adjust to the new customs and VAT arrangements, while others will seek to diversify into different markets.

\section{Tourism}

Tourism is the lifeblood of many local economies in Ireland. The promotion of tourism - overseas and domestic - is increasingly a key part of local government's economic development role. But with nonessential overseas travel discouraged, it was the year of the staycation. Economically, parts of Ireland were heavily exposed to the collapse of overseas tourism; therefore, big efforts were made by councils to entice domestic visitors. From interactive tourist maps to marketing campaigns and safety charters, the local authorities were involved in a range of promotional initiatives.

A Tourism Recovery Taskforce was set up in May - with local authority representation - and it published a tourist recovery plan for 2020-3. Developing the tourism product, working with local businesses, and effective marketing were all deemed crucial for 
winning back international tourists in the coming years. Post Covid, the taskforce expects that outdoor activities and sustainable tourism will gain in popularity (Department of Tourism, Culture, Arts, Gaeltacht, Sport and Media, 2020b). Therefore, investing in appropriate local attractions will be important.

Indeed, the PfG promises to work with local authorities and other agencies in the development of an integrated national network of greenways for tourists and other groups. Furthermore, it will invest in Ireland's blueways and recreational trails - much development work in tourism therefore lies ahead for councils (Department of the Taoiseach, 2020).

\section{Culture and heritage}

Artistic and cultural life across Ireland was severely disrupted by the necessity for public health restrictions. Many local events - organised or sponsored by councils - had to be cancelled from March onwards. Valiant efforts were made to relaunch festivals, exhibitions and performances as virtual events. Cultural spaces owned or supported by councils, such as theatres, museums and galleries, had to shut for long periods. Considerable efforts were undertaken to reopen such amenities and heritage sites as safely as possible when the government's guidelines permitted.

An Arts and Culture Recovery Taskforce - with a representative from the County and City Management Association - produced a report in October entitled Life Worth Living. It looked at how to address the severe challenges facing the arts and culture sector and contained a section on the local authorities' support role. The report warned of dire consequences for the sector if councils could not financially support it in 2021. Therefore, it wanted the Exchequer to cover any income lost by local authorities in 2021 to ensure the sponsorship of cultural events locally (Department of Tourism, Culture, Arts, Gaeltacht, Sport and Media, 2020a).

The PfG makes a number of commitments to protect Ireland's built heritage which will impact on local authorities:

- provision will be made so that councils have enough heritage officers and adequate funding to implement each county heritage plan;

- it will encourage the appointment of a Conservation and Repurposing Officer; 
- it will build on existing grant schemes to protect and maintain historic local buildings (Department of the Taoiseach, 2020).

\section{Housing issues}

Housing and homelessness were big election issues, and all parties put forward ideas on how to tackle the housing crisis (Shannon, 2020a). Certainly, housing was prominent in June's PfG: affordability, increased supply, homelessness prevention and rental regulation were the key planks of the new government's mission to secure 'Housing for All'. Furthermore, it seeks to 'ensure that local authorities are central to delivering housing'.

Some of the specific pledges were:

- provision of seed capital to councils to deliver serviced sites for affordable houses;

- expansion of the Rebuilding Ireland Home Loan scheme;

- increase the social housing stock by 50,000 units;

- a bigger role for the vacant homes officers and extra support for their work;

- publication of a rental needs assessment as part of local authority housing strategies (Department of the Taoiseach, 2020).

The initial lockdown (March-May) caused by Covid's emergence hampered social housing output across all delivery streams. Figures from the Department of Housing, Local Government and Heritage (DHLGH) show that by the end of Q3, the councils had built 766 new units and bought 324 units from the market. Just under 12,000 new households were accommodated through the Housing Assistance Payment over this period (Department of Housing, Local Government and Heritage, 2020h).

Data from the DHLGH shows that the number of people homeless in the country in November 2020 was 8,484 - a 19 per cent fall on the figure for 2019 (Department of Housing, Local Government and Heritage, 2020b). The moratorium on evictions, a rent freeze and the greater availability of rental accommodation for homeless people were decisive factors in this year's reduction (Focus Ireland, 2020). Whether this downward trend can be maintained post Covid will be a big question.

Under the July Stimulus Plan, an extra $€ 40$ million was provided to refurbish some 2,500 council units (Department of Housing, Local 
Government and Heritage, 2020e). Later in the year, Budget 2021 earmarked $€ 3.2$ billion for the DHLGH's housing budget $(€ 1.3$ billion for current and $€ 1.9$ billion for capital expenditure) (Department of Finance, 2020a). This budget - over 20 per cent bigger than last year's - underlined the new government's intent to tackle the housing problem. Indeed, the minister promised that local authorities, along with approved housing bodies, would undertake the 'biggest social housing build programme in the history of the State' (Department of Housing, Local Government and Heritage, 2020f).

\section{Environment}

With the Green Party back in government, environmental matters will receive even greater attention in the coming years. Under the PfG's mission to implement a 'Green New Deal', the councils will drive local initiatives in crucial areas like biodiversity, climate change, retrofitting of homes and water quality. Pledges in the programme include:

- ensuring that all local authorities have enough biodiversity officers;

- encouraging and supporting councils in the reduction of pesticide usage in public areas;

- supporting local authorities and groups to collaborate on biodiversity projects;

- continuing to support the Local Authority Waters Programme and expand the Community Water Development Fund (Department of the Taoiseach, 2020).

In October the Climate Action and Low Carbon Development (Amendment) Bill was published. Its section on the role of local authorities places a requirement on each authority to prepare a climate action plan every five years. The bill sets down a time frame by which the action plan has to be made and it must include both mitigation and adaptation measures. When making the plan, due consideration will have to be given to other relevant frameworks and plans, as well as ministerial guidelines and policies.

November saw the publication of the Environmental Protection Agency's 'State of the Environment' report - published every four years. From a local government perspective, the report highlighted the vital and challenging work that it carries out to protect Ireland's environment. However, it also flags some areas where progress is needed: 
- implementation of the actions and measures that are outlined in the climate change adaptation plans;

- better information sharing in the area of waste enforcement to help create a more effective enforcement system;

- noise planning guidance needs to be drafted for local authorities; they also need to take a stronger leadership role when dealing with noise pollution complaints;

- continued targeted action at the local level to arrest the deterioration of water quality in Ireland's water bodies (Environmental Protection Agency, 2020).

\section{Planning}

In October the Office of the Planning Regulator (OPR) published is first annual report. Set up in April 2019, the OPR had a busy first year. Its achievements included the examination of twenty-five local authority development plans, the making of thirty-one recommendations and sixteen observations on development plans, and the roll-out of a training programme for councillors on their role in the planning system. The report noted that there were 32,000 planning applications processed by Ireland's planning authorities in 2019, with almost 90 per cent of valid applications approved. There were more approvals for apartments than for housing; this is considered important to support sustainable living. However, it added a note of warning: the high number of houses given permission in Dublin's commuter belt undermines the planning objective of compact development in the capital (Office of the Planning Regulator, 2020a).

The year also saw the OPR launch an interactive map which provides the public with information on live public consultations for statutory plans (Office of the Planning Regulator, 2020b). It also published its Planning Research Framework, which seeks to address gaps in planning theory and practice, support best planning practice and promote public understanding of the planning system (Office of the Planning Regulator, 2020c).

The PfG proposes much change for the country's planning system:

- the introduction of a 'use it or lose it' clause for planning applications of ten or more units;

- the possible introduction of an independent Building Standards Regulator to oversee building control;

- a new scheme to encourage infill development; 
- reform the legislation dealing with compulsory purchase orders; strengthen the enforcement of the Vacant Site Levy;

- require each local authority to complete housing need and demand assessments to avoid the over-concentration of certain types of housing being developed (Department of the Taoiseach, 2020).

Some effects of the Covid crisis gave fresh impetus to debates on the sustainability of towns and cities and what type of future development is needed. The switch to remote working ended lengthy commutes for many workers; indeed, some have relocated to more affordable parts of the country to live. In the interests of public health, much work was undertaken by councils in 2020 to enhance public spaces and provide better infrastructure for mobility. Of course, the extent to which these changes become permanent remains to be seen; however, Covid's impact has already fed into local authority planning. For example, Carlow County Council's regeneration strategy for Carlow town repeatedly notes how the pandemic has underlined the importance of health and well-being considerations in the design of urban environments (Carlow County Council, 2020). Likewise, Longford County Council's draft county development plan for 2021-7 considers the longer-term implications of the pandemic on local development (Longford County Council, 2020).

\section{Finance}

At the start of 2020 the total expenditure by local authorities was budgeted at $€ 9.35$ billion ( $€ 5.6$ billion for revenue and $€ 3.75$ billion for capital expenditure) - an increase of 11 per cent on 2019. Income from commercial rates in 2020 was projected to be $€ 1.66$ billion (Department of Housing, Local Government and Heritage, 2020c). However, Covid's impact quickly punched a big hole in the expected incomes for local authorities in 2020.

Initially, in March, businesses forced shut by the public health restrictions could apply to their council for a deferral on the payment of commercial rates. But as the crisis deepened, councils waivered the collection of rates from impacted businesses as the Exchequer would make up the financial shortfall. Budget 2021 extended the rates waiver scheme until the end of 2020 and allocated $€ 900$ million to cover its cost for nine months (Department of Housing, Local Government and Heritage, 2020d). 
Non-rates income (from the likes of planning fees, car park and leisure facility charges) also deteriorated because of the Covid crisis. The issue of lost income affects all local authorities and will continue to raise much debate about their ability to deliver services into the future.

As part of the budget-making process for 2021, a record number of councils increased the basic rate of the Local Property Tax (LPT). Twenty-two opted to raise the basic rate, compared to nineteen councils the previous year. Three local authorities voted to decrease it, while six authorities opted to maintain the basic rate (Shannon, 2020b).

In November it was announced by the Minister of Finance, Paschal Donohoe, TD, that a decision on the LPT's re-evaluation would not be made until November 2021. This means that there will no change in LPT liabilities until at least 2022. The delay in forming a new government and the managing of the pandemic were cited by Donohoe as the reasons behind this move (Department of Finance, 2020b). This is the third time the re-evaluation has been deferred.

The PfG proposes to introduce legislation that will widen the LPT base to include properties currently exempt. Also, each local authority will be able to retain all the property tax income raised in its administrative area (Department of the Taoiseach, 2020).

\section{Customer satisfaction and performance}

The National Oversight and Audit Commission (NOAC) published its final satisfaction report for local authorities in September. Its findings are based on survey feedback from 1,000 citizens living in Ireland's ten smallest local authority areas. The previous two reports, published in 2018 and 2019, looked at Ireland's largest and medium-sized councils, respectively.

Some of the findings from the 2020 report include:

- 67 per cent of respondents thought that their council contributes positively to the quality of life in their area;

- 59 per cent of respondents were satisfied overall with their local council;

- 55 per cent felt that their local council is doing a good job;

- 48 per cent felt that they are well-informed by their council;

- 41 per cent thought that their council is open and transparent in its work (National Oversight and Audit Commission, 2020b). 
Taken together, the three reports paint a broadly positive picture of customer satisfaction with local government. Satisfaction levels with regards to 'value for money' and 'openness and transparency' were the lowest. Interestingly, the smaller councils tended to score higher than the larger ones.

In December NOAC issued its sixth Performance Indicator Report, covering 2019. It showed improvements in the collection of commercial rates, housing loans and rents. In addition, higher visitor traffic to council websites and increased levels of public engagement via social media were recorded. Against this, however, NOAC noted that improvements could be made in the areas of roads, property inspections and homelessness (National Oversight and Audit Commission, 2020a).

\section{Other developments}

The pandemic brought new ways of working for staff and elected members. In March many staff across local government were forced to work from home. As remote working was not an established work practice in local authorities, it initially posed a logistical and personal challenge for many involved. However, this flexible approach to work bedded down after several months and is very likely to remain an option for staff post Covid. Statutory council meetings were cancelled during the early months of the crisis; later, special arrangements were put in place to facilitate physically distanced meetings, often held in alternative venues. In October Minister O'Brien signed an order to enable councillors to hold statutory meetings and vote remotely (Department of Housing, Local Government and Heritage, 2020g).

Despite the disruption caused by Covid, the local authorities still managed to complete an impressive range of community projects and initiatives during the year. Some of these were celebrated by the Chambers Ireland Excellence in Local Government Awards announced in November (Chambers Ireland, 2020). The winners were spread across sixteen categories, and together they showcase the meaningful and practical change that councils help bring about in communities around the country.

At over 120 pages, the PfG contained many other commitments relating to local government. It vowed to make 'local government stronger, more accountable and more responsive to the communities it serves'. 
The matter of directly elected mayors (DEMs) is covered in the programme. Legislation will proceed for the election in 2021 of Limerick's first DEM; where demand is demonstrated, the government will enable the holding of plebiscites in 2024 on the question of DEMs in local authority areas for a five-year term. A Citizens' Assembly will be convened in 2021 to consider the best option regarding a DEM for Dublin.

Other commitments in the PfG include:

- a review of PPNs and local economic and community plans to assess their effectiveness on climate action and community development;

- make mandatory the establishment of a Strategic Policy Committee on climate change in each local authority;

- assess key performance indicators and update as necessary;

- enhance environmental enforcement capacity across local government;

- use Project Ireland 2040 to help regenerate regional towns (Department of the Taoiseach, 2020).

\section{Conclusion}

Because of the Covid-19 crisis, 2020 will live long in the collective memory as a year of immense global damage and suffering. In Ireland the local authorities were central to the government's response throughout the pandemic. From supporting the HSE to responding to the needs of vulnerable citizens and struggling businesses, the ability of councils to effectively reprioritise their work programmes demonstrated their flexibility and resourcefulness at a time of crisis.

With much unknown about the extent of Covid-19's threat in the early months of the emergency, local authorities developed innovative ways to support communities and businesses, whilst maintaining the delivery of essential services. The crisis also forced many local councils to accelerate the modernisation of their work practices and systems. There was much investment in information and communications technology across the sector, and post Covid it is likely that remote working (whether on a full-time or part-time basis) is here to stay for those staff who want it.

As the HSE's mass vaccination programme is rolled out in 2021, society should begin to return to some normality. Only then perhaps will a fuller understanding of the pandemic's impact on local 
government - especially in areas like finance and service delivery become clearer.

\section{References}

Carlow County Council. (2020). Project Carlow 2040: A vision for regeneration. Retrieved from https://consult.carlow.ie/en/consultation/masterplan [5 January 2021].

Chambers Ireland. (2020). ELG Awards 2020 winners. Retrieved from https://www.chambers.ie/events/elg-awards/winners-2020/ [8 January 2021].

Department of Enterprise, Trade and Employment. (2020). Restart grant press release. Retrieved from https://merrionstreet.ie/en/news-room/releases/ minister_humphreys_announces_that_local_authorities_are_now_taking _ applications_for_\% $\overline{\mathrm{E}} 2 \% 82 \% \mathrm{AC} 250 \mathrm{~m} \_$restart_grant.html [8 January 2021].

Department of Finance. (2020a). Draft budgetary plan 2021. Retrieved from http://www.budget.gov.ie/Budgets/2021/Documents/Budget/Irish\%20Draft $\%$ 20Budgetary\%20Plan\%202021.pdf [4 January 2021].

Department of Finance. (2020b). Minister Donohoe announces deferral of revaluation date for Local Property Tax (LPT) to 1 November 2021. Retrieved from https://www.gov.ie/en/press-release/ad612-ministerdonohoe-announces-deferral-of-revaluation-date-for-local-property-taxlpt-to-1-november-2021/ [4 January 2021].

Department of Housing, Local Government and Heritage. (2020a). Framework for local authority community support response. Dublin: Department of Housing, Local Government and Heritage.

Department of Housing, Local Government and Heritage. (2020b). Homeless report - November 2020. Retrieved from https://www.gov.ie/en/publication/ 73d33-homeless-report-november-2020/ [8 January 2021].

Department of Housing, Local Government and Heritage. (2020c). Local authority budgets 2020. Retrieved from https://www.gov.ie/en/collection/ 14e24-local-authority-budgets/ [8 January 2021].

Department of Housing, Local Government and Heritage. (2020d). Local authorities' role in response to pandemic 'vital', says Minister Burke. Retrieved from https://www.gov.ie/en/press-release/cf7fc-local-authoritiesrole-in-response-to-pandemic-vital-says-minister-burke/ [8 January 2021].

Department of Housing, Local Government and Heritage. (2020e). Minister O'Brien announces allocation of funds which will see over 2,500 vacant social housing units returned to use. Retrieved from https://www.gov.ie/en/pressrelease/17362-minister-obrien-announces-allocation-of-funds-which-willsee-over-2500-vacant-social-housing-units-returned-to-use/ [4 January 2021].

Department of Housing, Local Government and Heritage. (2020f). Minister O'Brien announces $€ 3.1$ billion housing budget. Retrieved from 
https:/www.gov.ie/en/press-release/96dba-minister-obrien-announces-31billion-housing-budget/ [4 January 2021].

Department of Housing, Local Government and Heritage. (2020g). Order signed to allow council meetings take place remotely. Retrieved from https:/www.gov.ie/en/press-release/300aa-order-signed-to-allow-councilmeetings-take-place-remotely/\#: : :text = Minister $\% 20$ for $\% 20$ Housing $\% 2 \mathrm{C} \% 20$ Local\%20Government,can\%20also\%20convene\%20remote\%20 meetings. [4 January 2021].

Department of Housing, Local Government and Heritage. (2020h). Social housing statistics. Retrieved from https://www.gov.ie/en/collection/6060eoverall-social-housing-provision/ [4 January 2021].

Department of Rural and Community Development. (2020). National volunteering strategy 2021-2015. Retrieved from https:/www.gov.ie/en/ publication/3cba6-national-volunteering-strategy/ [8 January 2021].

Department of the Taoiseach. (2020). Programme for government: Our shared future. Retrieved from https://www.gov.ie/en/publication/7e05dprogramme-for-government-our-shared-future/ [4 January 2021].

Department of Tourism, Culture, Arts, Gaeltacht, Sport and Media. (2020a) Life worth living: the report of the arts and culture recovery taskforce. Retrieved from https://www.gov.ie/en/press-release/4769e-arts-andculture-recovery-taskforce-report-published/ [8 January 2021].

Department of Tourism, Culture, Arts, Gaeltacht, Sport and Media. (2020b) Tourism recovery plan 2020-2023. Retrieved from https:/www.gov.ie/en/ publication/be0cb-tourism-recovery-plan-2020-2023/ [8 January 2021].

Environmental Protection Agency. (2020). Ireland's environment - An integrated assessment 2020. Retrieved from https://www.epa.ie/ pubs/reports/indicators/irelandsenvironment2020.html [8 January 2021].

Focus Ireland. (2020). Homeless figures and the impact of COVID-19. Retrieved from https://www.focusireland.ie/homeless-figures-and-theimpact-of-covid-19/ [5 January 2021].

Local Enterprise Offices. (2020). Look for local press release. Retrieved from https://www.localenterprise.ie/Laois/News/Latest-News/OVER-80-NOWLIKELY-TO-\%E2\% 80\%98LOOK-FOR-LOCAL\%E2\%80\%99-FORGOODS-AND-SERVICES.256420.shortcut.html [5 January 2021].

Longford County Council. (2020). Longford county development plan 20212027. Retrieved from https://www.longfordcoco.ie/longfordcoco/services/ planning/preparation-of-longford-cdp-2021-2027/ [8 January 2021].

National Oversight and Audit Commission. (2020a). Local authority performance indicator report 2019. Retrieved from https://noac.ie/ publications/ [8 January 2021].

National Oversight and Audit Commission. (2020b). Local authority satisfaction survey 2020. Retrieved from https://noac.ie/publications/ [8 January 2021].

Office of the Planning Regulator. (2020a). Annual report 2019. Retrieved from https://www.opr.ie/office-of-the-planning-regulator-launches-first-annualreport/ [5 January 2021]. 
Office of the Planning Regulator. (2020b). Interactive map press release. Retrieved from https://www.opr.ie/opr-launches-new-interactive-mapdisplaying-information-on-statutory-plans/ [5 January 2021].

Office of the Planning Regulator. (2020c). Planning research framework. Retrieved from https://www.opr.ie/publications/ [5 January 2021].

Shannon, L. (2020a, Spring). General election 2020. Local Authority Times, 23 (1)

Shannon, L. (2020b, Winter). Local property tax. Local Authority Times, 23 (3). 